\title{
Six-hour central venous oxygen saturation has no prognostic value in patients with septic shock
}

\author{
KM Yoo ${ }^{1 *}$, KS Kim ${ }^{1}$, GJ Suh ${ }^{1}$, WY Kwon ${ }^{1}$, JS Kim ${ }^{1}$, MJ Park ${ }^{1}$, YJ Choi ${ }^{1}$, K Kim $^{2}$ \\ From ESICM LIVES 2015 \\ Berlin, Germany. 3-7 October 2015
}

\section{Intr}

Central venous oxygen saturation ( $\mathrm{Scv02}$ ) is used as an indicator of adequate tissue oxygenation and current sepsis guideline includes Scv02 70\% or more as one of initial resuscitation goals during the first 6 hours. However, it is still controversial that to achieve Scv02 goal is mandatory.

\section{Objectives}

The aim of this study was to investigate the prognostic value of 6-hour Scv02 to predict the 1-month mortality in patients with septic shock.

\section{Methods}

We have retrospectively identified septic shock patients who received protocolized treatment in two tertiary academic EDs. All patients were treated using the early goaldirected protocol. The data with respect to demographics, predisposing factors, site of infection, and the admission APACHE II score were collected. Hemodynamic (mean arterial pressure and central venous pressure) and laboratory (arterial blood gas analysis, Scv02, and lactate level) parameters at baseline and 6-hour were also recorded. To test the prognostic value of 6-hour Scv02, the area under receiver operating characteristics curve (AUROC) to predict 1-month mortality was calculated and compared with that of 6-hour lactate level. Pearson correlation coefficient between 6-hour Scv02 or lactate level and the admission APACHE II score were also analyzed.

\section{Results}

After excluding 122 patients with missing variables, 424 were analyzed. Among them, 104 (24.5\%) died within 1 -month. Respiratory infection was more frequently observed in 1-month mortality group. Lower 6-hour mean

Seoul National University Hospital, Department of Emergency Medicine, Seoul, Korea, Republic of Korea

Full list of author information is available at the end of the article

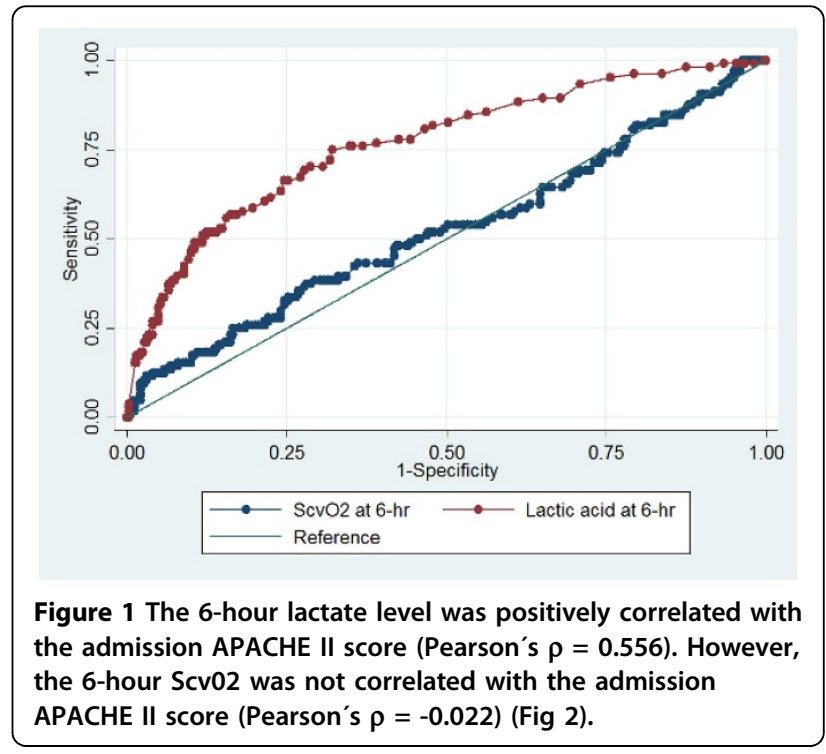

arterial pressure, higher baseline and 6-hour lactate levels, and higher admission APACHE II score were associated with an increase in the 1-month mortality. The AUROC of 6-hour Scv02 to predict 1-month survival was 0.525 (95\% confidence interval, 0.458-0.592). AUROC of 6-hour lactate level to predict 1 -month mortality was 0.767 (0.713-0.821), which was significantly higher than that of 6-hour Scv02 ( $<$ 0.001) (Figure 1).

\section{Conclusions}

The 6-hr Scv02 has no prognostic value in patients with septic shock. Targetting Scv02 goal $\geq 70 \%$ may not be essential in the management of septic shock.

\section{Authors' details}

'Seoul National University Hospital, Department of Emergency Medicine, Seoul, Korea, Republic of Korea. ${ }^{2}$ Seoul National University Bundang Hospital, Department of Emergency Medicine, Seongnam-si, Korea, Republic of Korea. 

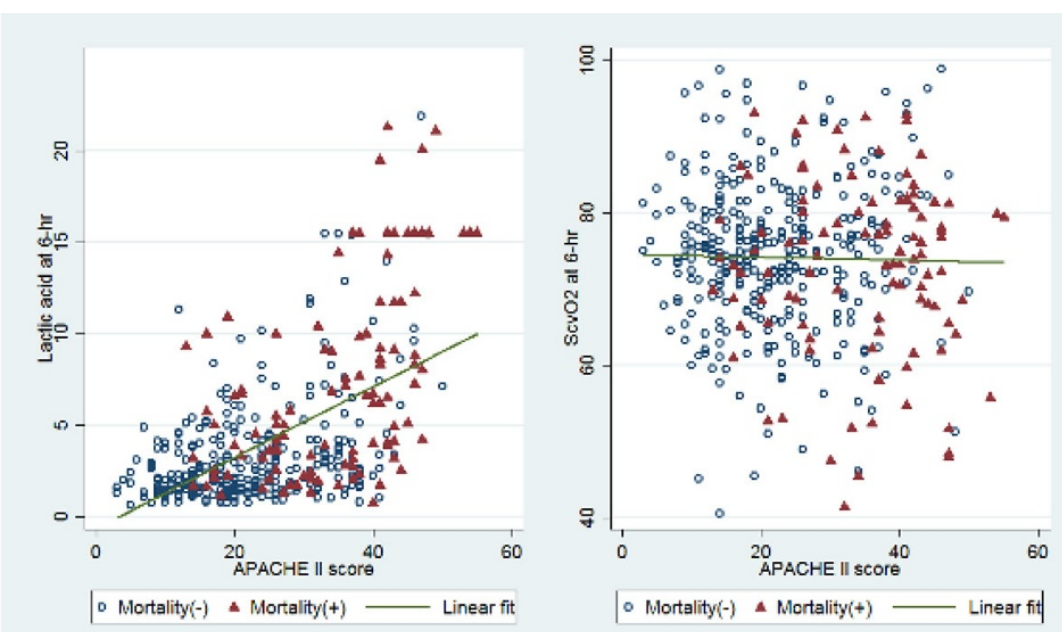

Figure 2

Published: 1 October 2015

\section{References}

1. Rivers E, Nguyen B, Havastad S, et al: Early goal-directed therapy in the treatment of severe sepsis and septic shock. N Engl J Med 2001, 345:1368-77.

2. Dellinger RP, Levy MM, Rhodes A, et al: Surviving Sepsis Campaign: international guidelines for management of severe sepsis and septic shock. 2012. Intensive Care Med 2013, 39:165-228.

3. ProCESS Investigators, Yearly DM, Kellum JA, Huang DT, et al: A randomized trial of protocol-based care for early septic shock. $N$ Engl J Med 2014, 370:1683-93.

doi:10.1186/2197-425X-3-S1-A220

Cite this article as: Yoo et al: Six-hour central venous oxygen saturation has no prognostic value in patients with septic shock. Intensive Care Medicine Experimental 2015 3(Suppl 1):A220.

\section{Submit your manuscript to a SpringerOpen ${ }^{\circ}$ journal and benefit from:}

- Convenient online submission

- Rigorous peer review

- Immediate publication on acceptance

- Open access: articles freely available online

- High visibility within the field

- Retaining the copyright to your article

Submit your next manuscript at $\gg$ springeropen.com 